\title{
Model Islam Inklusif Di Indonesia Sebagai Kajian Kritik Terhadap Teori "Clash Of Civilizations" Samuel P. Huntington
}

\author{
Info Artikel \\ Dikirim: 28 Nov, 2021 \\ Diterima: 25 Jan, 2022 \\ Dipublikasi: 31 Jan, 2022 \\ Kata Kunci: \\ Clash of Civilization Theory; \\ Islam Berkemajuan; Islam \\ Nusantara; Muhammadiyah; \\ Nahdlatul Ulama;
}

Ardli Johan Kusuma ${ }^{1}$, Restu Rahmawati ${ }^{1}$, La Ode Muhammad Fathun ${ }^{2}$

${ }^{1}$ Program Studi Ilmu Politik, Universitas Pembangunan Nasional Veteran Jakarta, 12540, Jakarta-Indonesia

${ }^{2}$ Program Studi Hubungan Internasional, Universitas Pembangunan Nasional Veteran Jakarta, 12540, Jakarta-Indonesia
Koresponden:

Ardli Johan Kusuma

Prodi Ilmu Politik, Universitas Pembangunan Nasional Veteran Jakarta, 12540, JakartaIndonesia

Email:

Ardli.johan@yahoo.com

\section{Sitasi Cantuman:}

Kusuma, A. J., Rahmawati, R. \& Fathun, L. M., (2022). Model Islam Inklusif $\mathrm{Di}$ Indonesia Sebagai Kajian Kritik Terhadap Teori "Clash Of Civilizations" Samuel P. Huntington. Journal of Political Issues. 3(2); 62-76. https://doi.org/10.33019/jpi.v3i 2.71

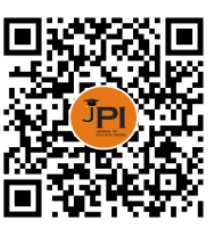

DOI:

https://doi.org/10.33019/jpi.v3i 2.71

Lisensi:

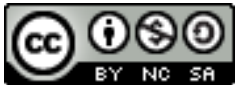

Attribution-NonCommercialShareAlike 4.0 International (CC- BY-NC-SA 4.0)

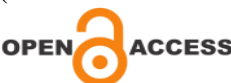

\begin{abstract}
ABSTRAK
Abstract This article explores the phenomenon of the inclusive Islamic model that exists in Indonesia, as a critical study of Samuel P. Huntington's "Clash of Civilization" theory. The results of the discussion in this article have shown some of the weaknesses of the "Clash of Civilization" theory developed by Samuel P. Huntingtong, especially when viewed from a theoretical and historical approach. For example, there are inconsistencies in using the realist paradigm in the development of the theory. In addition, Huntington also experienced confusion to choose between a geographical basis or a religious basis in identifying the civilization in question. And historical facts have also shown that many conflicts that occur in this world are not based on differences in civilization. Moreover, it is found that the discussion on the Islamic dimension in the book only takes references from Middle Eastern Islam, which is in stark contrast to the phenomenon of the Nusantara Islam model practiced by Nahdlatul Ulama and Progressive Islam practiced by Muhammadiyah in Indonesia. The point of this article is to show that there is a contradictory phenomenon shown by Islamic civilization in Indonesia which is very contradictory to the discussion of the Islamic dimension in Huntington's book. Indonesia, which is the country with the largest Muslim population in the world, with the inclusive Islamic model in it has been able to show a different dimension of Islam from what Huntington describes in his book. The Nusantara Islam model pioneered by the largest Islamic organizations in Indonesia and even the world, namely NU (Nahdlatul Ulama) and Muhammadiyah has been able to demonstrate an Islamic model that is moderate, anti-radical, inclusive, and tolerant.

Abstrak Tulisan artikel ini mengeksplorasi tentang fenomena model Islam inklusif yang ada di Indonesia, sebagai suatu kajian kritik terhadap teori "Clash of Civilization" Samuel P. Huntington. Adapun hasil pembahasan dalam artikel ini telah menunjukkan tentang beberapa kelemahan dari teori "Clash of Civilization" yang dibangun oleh Samuel P. Huntingtong, terutama jika dilihat dari pendekatan teoritis maupun pendekatan sejarah. Misalnya saja adanya inkonsistensi dalam menggunakan paradigma realis dalam pembangunan teorinya. Selain itu Huntington juga mengalami kebingugan untuk memilih antara landasan geografis ataukah landasan agama dalam mengidentifikasi peradaban yang dimaksud. Serta fakta sejarah juga telah menunjukkan bahwa banyak konflik yang terjadi di dunia ini tidak didasari oleh adanya perbedaan peradaban. Terlebih lagi ditemukan fakta bahwa pembahasan tentang dimensi Islam dalam buku tersebut hanya mengambil referensi dari Islam Timur Tengah, yang sangat bertolak belakang dengan fenomena model Islam Nusantara yang dipraktikkan oleh Nahdlatul Ulama dan Islam Berkemajuan yang dipraktikkan Muhammadiyah di Indonesia. Inti dari artikel ini adalah ingin menunjukkan adanya fenomena yang bertolak belakang yang ditunjukkan peradaban Islam di Indonesia yang sangat bertolak belakang dengan pembahasan dimensi Islam dalam buku yang ditulis Huntington. Indonesia yang menjadi negara dengan jumlah penduduk beragama Islam terbesar di dunia, dengan model Islam inklusif yang ada di dalamnya telah mampu menunjukkan dimensi Islam yang berbeda dengan apa yang digambarkan oleh Huntington dalam bukunya tersebut. Model Islam Nusantara yang dipelopori oleh organisasi Islam terbesar di Indonesia bahkan dunia yaitu NU (Nahdlatul Ulama) dan Muhammadiyah telah mampu menunjukkan model Islam yang bersifat moderat, anti radikal, inklusif, dan toleran..
\end{abstract}

Tentang:

Ardli Johan Kusuma, Menyelesaikan Studi S3 di Univeristas Muhammadiyah Yogyakarta pada tahun 2020. Saat ini penulis merupakan dosen di Program Studi Ilmu Politik Universitas Pembangunan Nasional Veteran Jakarta. 

Restu Rahmawati, menyelesaikan studi S2 di Universitas Gadjah Mada pada tahun 2012. Saat ini penulis merupakan dosen di Program Studi Ilmu Politik Universitas Pembangunan Nasional Veteran Jakarta.

La Ode Muhammad Fathun, menyelesaikan studi S2 di Universitas Muhammadiyah Yogyakarta pada tahun 2016. Saat ini penulis merupakan dosen di Program Studi Ilmu Politik Universitas Pembangunan Nasional Veteran Jakarta.

\section{PENDAHULUAN}

Setelah berakhirnya perang dingin, yang kemudian ditandai dengan peristiwa terpecahnya Uni Soviet pada tahun 1991, yang mana hal tersebut berdampak pada munculnya "pemenang" yaitu blok barat di bawah kepemimpinan Amerika Serikat, yang membuat masyarakat internasional tidak lagi dihantui kecemasan akan terjadinya perang besar seperti perang dunia pertama ataupun perang dunia kedua. Mengingat ketika itu perang dingin melibatkan dua kekuatan besar yang siap meledak kapanpun, karena masing-masing pihak baik blok barat maupun blok timur sama-sama memiliki senjata nuklir yang bisa menghancurkan dunia. Namun kecemasan tersebut segera menghilang setelah Uni Soviet bubar. Setelah berakhirnya perang dingin tersebut, muncul keyakinan bahwa dunia internasional tidak lagi menghadapi ancaman terjadinya konflik besar, terlebih lagi, konflik yang didasari adanya perbedaan ideologi. Keyakinan tersebut, setidaknya didasarkan pada teori yang dikembangkan oleh Francis Fukuyama, dimana dia berpendapat bahwa dengan berakhirnya perang dingin merupakan akhir dari sejarah itu sendiri, yaitu titik akhir dari proses evolusi ideologis manusia dan kemudian memunculkan universalisasi demokrasi liberal Barat sebagai bentuk final pemerintahan yang diterapkan umat manusia (Fukuyama, 2004).

Namun anggapan bahwa dunia akan damai mulai diragukan setelah muncul pemikiran dari seorang guru besar sekaligus ketua jurusan Ilmu Politik dari Universitas Harvard, yang juga menjadi ketua Harvard Academy untuk kajian Internasional dan Regional di Weatherhead Center For International Affairs, yang bernama Samuel Philips Huntington, mengeluarkan sebuah tesis yang merupakan anti-tesis dari Francis Fukuyama. Tesis dari Samuel P. Huntington tersebut dijabarkan secara lengkap dalam sebuah buku yang telah diterbitkannya pada tahun 1996 dengan judul "The Clash of Civilization and the Remaking of World Order" (Benturan Antar Peradaban dan Masa Depan Politik Dunia).

Dalam bukunya tersebut, Huntington membuat argumen yang bertentangan dengan Fukuyama. Jika Fukuyama mengatakan bahwa dunia akan damai setelah kemenangan ideologi demokrasi yang liberal sehingga negara-negara tidak akan lagi mengalami konflik atau benturan ideologi, maka Huntington berpendapat bahwa pasca perang dingin diprediksikan masih akan tetap terjadi benturan. Huntington dengan percaya diri mengajukan sebuah tesis bahwa pasca perang dingin dunia ini akan memasuki dalam sebuah era dimana benturan kebudayaan akan terjadi. Konflik atau benturan yang didasari oleh identitas dari beberapa kelompok yang juga sudah dipetakan oleh Huntington akan mendominasi bentukbentuk gesekan yang akan terjadi pasca perang dingin.

Dalam tesisnya tersebut, Huntington membagi peta dunia ke dalam tujuh atau delapan peradaban besar. kekuatan-kekuatan dunia dibagi berdasarkan teritori di bawah kontrol politis berbagai peradaban di dunia. Diantaranya adalah: Barat, Afrika, Cina, Hindu, Islam, Jepang, Amerika Latin, Ortodoks, dan Lainnya (peradaban-peradaban kecil yang tersebar di seluruh dunia) (Huntington, 2012). Tetapi satu hal yang menjadi menarik dalam tesis tersebut adalah, Huntington menyebutkan bahwa intensitas benturan peradaban yang paling banyak terjadi, baik yang telah terjadi di masa lampau, ataupun yang akan terjadi di masa depan (menurut prediksi Huntington) adalah benturan antara dua peradaban besar dunia yaitu peradaban barat dengan peradaban Islam. 
Perbedaan peradaban dan identitas diprediksikan oleh Huntington akan menjadi pemicu terjadinya bentuk benturan-benturan yang akan terjadi "dalam dunia baru". Konflik yang nantinya akan paling mudah menyebar sekaligus paling berbahaya, justru bukanlah konflik yang terjadi antar kelas sosial, antara golongan kaya dengan golongan miskin, atau antar kelompok (kekuatan) ekonomi yang lainnya. Konflik justrua akan muncul antara orangorang yang memiliki entitas-entitas budaya yang berbeda-beda. Perselisihan antar suku dan konflik antar etnis dalam konteks peradaban akan senantiasa terjadi. Kekerasan yang terjadi dkarena disebabkan terjadinya konflik antar negara dan antar peradaban, secara langsung maupun tidak langsung akan mengundang negara-negara dan kelompok-kelompok peradaban lain untuk memberikan dukungan terhadap negara-negara atau kelompok-kelompok yang dianggap semiliki entitas yang sama. Perbedaan kebudayaan atau identitas akan memicu terjadinya konflik yang bersifat lokal. Kemudian konflik yang bersifat lokal tersebut akan meluas secara global. Itulah pemikiran Huntington yang dikembangkan dalam bukunya yang berjudul "The Clash of Civilization and the Remaking of World Order".

Masyarakat Internasional banyak yang mengalami kekhawatiran terkait teori Huntington tersebut jika benar-benar terjadi. Mengingat peradaban Islam dan peradaban barat, serta peradaban yang lain merupakan suatu komunitas manusia yang sangat besar. Sehingga ditakutkan akan terjadi konflik dengan skala yang besar. Negara Indoensia yang merukapak negara muslim terbesar di dunia (dilihat dari jumlah penduduk yang beragama Islam), tentunya bukan tidak mungkin akan terseret pada kondisi konflik seperti yang digambarkan oleh Huntington tersebut. Pew Research Centers Forum on Religion and Public Life telah merilis hasil survey yang dilakukannya pada tahun 2009 yang memetakan penduduk muslim secara global. Hasilnya antara lain, pemeluk agama Islam berjumlah 1,57 miliar atau setara dengan (23\%) dari jumlah total penduduk dunia yaitu sebanyak 6,8 miliar. Sementara itu, sebagian besar umat Islam menetap di wilayah Asia yaitu sebanyak (60\%), yang mana sebanyak $20 \%$ ada di Timur Tengah dan Afrika Utara. Indonesia merupakan negara muslim terbesar dengan pemeluk Islam yang berjumlah 203 juta atau setara dengan (13\%) dari total penduduk muslim di dunia, dan juga, Indonesia dianggap sebagai negeri paling religius (Mufid, 2013). Sebagai negara yang menyandang gelar negara Islam terbesar di dunia, Indonesia tidak terlepas dari permasalahan yang bersinggungan dengan masalah budaya ataupun peradaban. Terlebih lagi posisi Indonesia yang merupakan negara yang memiliki corak masyarakat yang beragam kebudayaannya dari sabang sampai merauke. Tidak hanya dari segi budaya, namun secara segi agama pun Indonesia merupakan negara yang multi agama, dimana Indonesia memiliki lima agama resmi yaitu: Islam, Kristen, Katolik, Hindu, Budha, dan beberapa agama yang lain. Yang secara resmi dilindungi oleh pemerintah Indonesia.

Keberagaman Indonesia jika dilihat dari teori benturan antar peradaban maka potensi gesekan atau benturan di Indonesia sangat tinggi. Tantangan itu juga dihadapi oleh Islam di Indonesia, karena Islam masuk ke Indonesia setelah agama Hindu dan Budha yang sudah berkembang lebih dulu di Indonesia. Namun sejarah sudah membuktikan bahwa masuknya agama Islam di Indonesia dilakukan secara damai. Tidak hanya itu, setelah Islam berkembang di Indonesia dan berhasil menjadi agama yang diyakini oleh sebagian besar masyarakat di Indonesia, tidak lantas mebuat agama Islam di Indoensia melakukan hegemoni budaya dan menghilangkan peradaban non-Islam di Indonesia. Yang terjadi justru sebaliknya, dimana mayoritas masyarakat Islam di Indonesia mampu mengakulturasikan peradaban non-Islam dengan peradaban Islam yang berkembang itu sendiri. Kondisi tersebut menunjukkan pola yang berbeda dengan apa yang telah diprediksikan oleh Huntingtan terkait akan terjadinya benturan peradaban. Islam mayoritas di Indonesia ternyata menunjukkan bahwa Islam mampu melakukan pendekatan yang akulturatif dengan peradaban non-muslim yang sebenarnya sudah lama hidup di Indonesia sebelum Islam itu sendiri masuk. 


\title{
2. METODE PENELITIAN
}

Tulisan ini bertujuan untuk mengetahui bagaimana praktik Islam inklusif di Indonesia yang kemudian digunakan sebagai studi kritis dalam melihat teori "Clash of Civilization" yang telah pemprediksikan bahwa pasca perang dingin akan terjadi benturan antar peradaban, dimana menurut Huntington yang paling banyak intensitas benturannya adalah peradaban barat dan Islam. Tulisan ini akan mencoba menganalisa bagaimana Huntington menggambarkan Islam dalam bukunya yang berjudul "The Clash of Civilization and the Remaking of World Order", dengan mendiskripsikan praktik Islam yang inklusif di Indensia sebagai negara Islam terbesar di dunia. Sehingga hasil studi ini diharapkan dapat memberikan gambaran bahwa model Islam yang dipraktikkan di negara Islam terbesar di dunia (Indonesia) menunjukkan fakta yang sebaliknya dari apa yang digambarkan oleh Huntington dalam bukunya. Penelitian ini merupakan penelitian kualitatif, dimana seluruh data akan disajaikan dalam bentuk kalimat. Sementara data dikumpulkan dengan studi literatur dimana data dikumpulkan dari berbagai sumber literatur seperti: dokumen resmi, jurnalistik baik cetak maupun online, jurnal ilmiah, buku, serta sumber website yang dianggap memenuhi syarat untuk dijadikan rujukan.

\section{HASIL DAN PEMBAHASAN \\ Teori "Clash of Civilization"}

Huntington, telah mengemukakan bahwa politik dunia saat ini telah memasuki fase yang baru. Hal ini dbarengi dengan munculnya para intelektual yang sudah berani mengembangkan visi-visi pemikiran tentang apa yang akan terjadi di masa yang akan datang. misalnya saja visi berakhirnya sejarah, kemudian kembalinya lawan-lawan tradisional di antara negara bangsa, serta runtuhnya negara bangsa yang disebabkan oelh adanya tarikmenarik yang disertai munculnya konflik antara tribalisme dan globalisme. Huntington sendiri telah melakukan sebuah studi yang kemudian merumuskan sebuah teori yang bersifat "prediktif", dimana dia memprediksi bahwa konflik-konflik yang akan terjadi dalam dunia modern (pasca perang dingin) tidak lagi dipengaruhi oleh faktor-faktor ideologi ataupun faktor-faktor ekonomi. Melainkan konflik yang terjadi akan lebih dilatar belakangi oleh perbedaan peradaban. Dimana Huntington dalam artikelnya menyebutkan:

\begin{abstract}
"It is my hypothesis that the fundamental source of conflict in this new world wil not be primarily ideological or primarily economic. The great divisions among humankind and the dominating source of conflict will be cultural. Nation state will remain the most powerful actors in world affairs, but the pricipal conflicts of global politics will occur between nations and groups of different civilizations. The clash of civilizations will be the battle lines of the future" (Huntington, 1993).
\end{abstract}

Dari pernyataan tersebut, dengan jelas Huntington telah berteori mengenai pola-pola konflik dunia modern atau era pasca perang dingin. Dimana dalam prediksinya, konflikkonflik yang akan terjadi akan dipengaruhi karena adanya benturan peradaban, terutama peradaban Islam dan peradaban barat.

Teori benturan peradaban (Clash of Civilizaton) yang dikemukakan Huntington merupakan bentuk responnya terhadap pendapat Francis Fukuyama, dimana dalam bukunya yang berjudul "The End of History and The Last Man", yang diterbitkan tahun 1992, dimana dia berpendapat bahwa dengan berakhirnya perang dingin akan menjadikan akhir dari sejarah itu sendiri. Hal tersebut akan menjadi titik akhir dari evolusi ideologis manusia, dan memunculkan universalisasi demokrasi liberal Barat sebagai bentuk final pemerintahan yang akan diterapkan oleh umat manusia. Fukuyama berpendapat bahwa setelah kelompok liberal 
memenangkan perang dingin maka itulah berakhirnya sejarah dinamika ideologi. Karena dia berpendapat bahwa menangnya Amerika Serikat dan sekutunya menandai bahwa ideologi demokrasi liberal merupakan ideologi yang secara universal dapat diterima dan akan membuat dunia damai. Karena menurutnya tidak akan ada lagi benturan ideologi atau perang, karena sisten demokrasi yang digunakan secara universal akan mencegah peperangan atau benturan antar negara.

Bermula dari situ, kemudian Huntington melakukan sebuah studi yang kemudian dia menghasilkan teori benturan antar peradaban yang merupakan bentuk pertentangan atau antitesis dari teori Francis Fukuyama. Sementara pemahaman tentang peradaban yang dijelaskan Huntington juga perlu dipahami untuk bisa melihat secara utuh apa yang dimaksud oleh Huntington tentang benturan antar peradaban. Dalam bukunya yang berjudul "The Clash of Civilization and the Remaking of World Order", dia mendefinisikan apa yang dimaksud dengan peradaban. Namun sebelumnya Huntington juga telah merujuk pada beberapa pengertian peradaban menurut para ahli yang lain. Diantaranya adalah, pemikiran Braudel yang mendefinisikan peradaban sebagai wilayah kultural (sekumpulan karakteristik dan fenomena kultural). Sementara menurut Wallerstein, peradaban diartikan sebagai seperangkat pandangan dunia, atau kebiasaan-kebiasaan, struktur-struktur (sosial) dan kebudayaan tertentu (baik kebudayaan material maupun bentuk kebudayaan-kebudayaan yang lebih tinggi) yang kemudian membentuk berbagai corak kesejarahan dan eksistensinya yang bersifat simultan dengan keberadaan anekaragam fenomena-fenomena yang lain. Kemudian peradaban menurut Dawson dimaknai sebagai sebuah produk dari "suatu proses tertentu dari kreativitas budaya yang merupakan hasil karya dari sekelompok orang (atau masyarakat tertentu). Sementara bagi Durkheim dan Mauss, peradaban dianggap sebagai suatu corak "wilayah" moral yang dilingkupi sebuah bangsa, dengan kebudayaan masingmasing yang hanya menjadi suatu bentuk tertentu dari keseluruhan. Dari beberapa pemikir tersebut Huntington, dalam bukunya menyimpulkan bahwa Peradaban adalah entitas paling luas dari bentuk budaya (Huntington, 2012).

Dalam melakukan konseptualisasi mengenai peradaban Huntington menjelaskan lebih jauh dengan mengatakan bahwa: darah, bahasa, agama, pandangan hidup merupakan faktor yang bisa mencirikan sebuah masyarakat tertentu. Namun dia menambahkan bahwa seluruh faktor objektif yang merumuskan berbagai bentuk corak peradaban, faktor yang paling mempengaruhi corak peradaban pada umumnya adalah "faktor agama". Hal tersebut menunjukkan kebingungan Huntington dalam merumuskan konseptual serta pembagian peradaban dunia. Apakah dunia ini mau dibagi atas peradaban berdasarkan agama, wilayah geografis atau berdasarkan bentuk yang lain.

Namun jika dilihat lebih cermat lagi dalam bukunya, Huntington mencoba untuk menutupi kebingungannya dengan menekankan agama sebagai pengaruh utama dalam mengidentifikasi sebuah peradaban. Lebih utama lagi peradaban dunia ini utamanya dipengaruhi oleh agama Kristen dan Islam yang dianggap ua agama ini paling banyak menaungi kelompok-kelompok masyarakat pada level terkecil yang berasal dari berbagai suku bangsa (Huntington, 2012). Dari kompleksitas dan sulitnya memahami peradaban, Huntington menekankan pada faktor agama yang mempengaruhi peradaban. Dan dalam konteks teorinya tentang benturan peradaban maka agama Islam dan agama Kristen adalah yang paling berpengaruh, sekaligus sebagai peradaban yang paling keras benturannya.

\section{Pembahasan Dimensi "Islam" Dalam Buku "The Clash of Civilization and the Remaking of World Order"}

Huntington memprediksikan bahwa intensitas benturan peradaban yang paling banyak terjadi (menurut prediksi Huntington) adalah benturan antara dua peradaban besar dunia yaitu peradaban barat dengan peradaban Islam. Untuk itu dalam bukunya, Huntington telah banyak 
membahas mengenai Islam. Dimana secara garis besar Huntington memecah bukunya kedalam lima bagian utama. Dari ke-lima bagian dalam buku tersebut, setidaknya ada dua bagian yang terdiri dari tidak kurang dari enam sub-judul, yang secara khusus membahas tentang Islam dan hubungannya dengan barat.

Dua dari lima bagian yang membahas secara khusus tentang Islam adalah bab ke-dua dan bab ke-empat dalam buku "The Clash of Civilization and the Remaking of World Order" tersebut. Adapun dalam bagian ke-dua, Huntington menempatkan Islam sebagai pihak peradaban yang menyebabkan terjadinya destabilisasi di dunia internasional yang berdampak pada negara-neagra non-Islam termasuk negara-negara barat. Dalam penjelasannya Huntington menyebutkan "Negara-negara Islam mengalami ledakan penduduk yang berdampak pada destabilisasi yang tidak hanya menimpa negara-negara Islam itu sendiri, tetapi juga negara-negara tetangga mereka; dan peradaban-peradaban non-barat secara umum menegaskan kembali nilai-nilai budaya mereka sendiri” (Huntington, 2012).

Secara jelas Huntington menyimpulkan bahwa pertumbuhan penduduk muslim di dunia yang menyebabkan terjadinya destabilisasi di dunia internasional. Islam seolah menjadi "trouble maker" dalam kasus terjadinya benturan antar peradaban yang menyebabkan dunia tidak stabil. Selain itu Huntington juga menunjukkan rasa kekhawatiran dari pihak barat terhadap bangkitnya peradaban non-barat, dalam hal ini tentu saja yang paling ditakuti adalah peradaban Islam. Hal itu terlihat dari pernyataan Huntington yang menggambarkan kecemasan barat ketika masyarakat non-barat, termasuk Islam mulai menjunjung nilai-nilai budaya mereka sendiri.

Kemudian pembahasan secara khusus tentang Islam dalam bukunya Huntington dimasukkannya kedalam bagian ke-empat. Dimana dalam bagian empat tersebut Huntington membangun konstruksi kesimpulan bahwa konflik yang terjadi antara kaum muslim dan kaum non-muslim menyebabkan terjadinya pecah konflik secara global. Karena menurutnya negara-negara yang merasa serumpun akan memberikan dukungannya. Dalam bagian tersebut Huntington mengambil contoh konflik yang terjadi di negara-negara Islam untuk menguatkan argumennya bahwa konflik yang terjadi pada level lokal oleh kaum muslim menyebabkan pecah konflik yang berskala global. Dalam membangun opini Huntington menggunakan contoh-contoh seperti perang di Afganistan, perang teluk, konflik Arab dan Israel, konflik kelompok syi'i Lebanon dengan kelompok Maronit. Huntington ingin membangun sebuah pandangan bahwa konflik lokal yang terjadi atau yang dialami kaum muslim, menjadi penyebab pecahnya konflik yang lebih luas. Sehingga dalam hal ini Islam ditempatkan pada objek peradaban yang menyebabkan terjadinya benturan peradaban. Secara keseluruhan, Huntington lebih banyak berbicara soal konflik yang akan terjadi antara Islam dan barat. Namun Huntington banyak melakukan kesalahan ketika melakukan penjabaran soal Islam. Huntington terlalu menempatkan Islam pada posisi yang tidak menguntungkan dalam kasus ini. Islam dijadikan objek penempatan kesalahan sekaligus penyebab konflik. Konstruksi mengenai cerita-cerita yang tidak menguntungkan bagi umat Islam ini kemudian memancing berbagai tanggapan yang bersifat mengkritik terhadap buku karya Huntington yang berjudul "The Clash of Civilization and the Remaking of World Order". Karena memang ada beberapa hal yang kurang tepat yang telah dilakukan Huntington dalam menggambarkan Islam. selain itu ada juga beberapa kelemahan atas konstruksi bangunan teori yang diajukan Huntington.

Secara pendekatan teoritis misalnya, terdapat kelemahan yang dilakukan oleh Huntington dalam membangun teorinya. Dimana terdapat inkonsistensi pendekatan yang dilakukan oleh Huntington. Dia tidak konsisten dalam menggunakan pendekatan paradikma realis dalam disiplin Ilmu Hubungan Internasional. Padahal Huntington ingin menghasilkan bagian dari teori " World power politics" dimana teori tersebut termasuk dalam paradikma realis dalam disiplin Ilmu Hubungan Internasional. Namun ketika Huntington menjelaskan mengenai pembentukan aliansi dalam dunia internasional, justru Huntington menempatkan 
peradaban sebagai landasan atau dasar pembentukan sebuah aliansi. Dimana menurut Mian Muhammad, untuk mengidentifikasi dasar dari pembentukan aliansi akan lebih tepat jika menggunakan teori kepentingan nasional yang merupakan bagian dari paradikma realis dalam Ilmu Hubungan Internasional, bukannya menggunakan landasan peradaban seperti yang diakukan Huntington. Selain itu teori Huntington juga memiliki kelemahan dalam pendekatan unit analisis yang digunakan. Dimana unit analisa yang digunakan oleh Huntington adalah peradaban. Namun Huntington gagal mendefinisikan peradaban yang seharusnya definisi tersebut bisa dipahami sebagai pemahaman universal sebagai peradaban, karena peradaban merupakan entitas yang sangat besar, sehingga dibutuhkan pendefinisian yang bisa dipahami secara universal. Selain itu Huntington juga telah gagal dalam mendefinisikan peradaban Islam. Dalam membangun argumen dalam teorinya, Huntington lebih mengedepankan prinsip-prinsip geografis dalam membagi peradaban dunia. Sementara Islam merupakan agama yang universal, sehingga peradaban Islam tidak bisa dibatasi oleh prinsip-prinsip geografis yang memisahkan antar peradaban sebagaimana telah disampaikan Huntington. Sehingga Huntington telah gagal dan salah total dalam mengidentifikasi peradaban Islam yang seharusnya bersifat universal tanpa dibatasi oleh batas-batas geografis (Ashraf, 2012).

Selain itu Huntington juga telah melakukan generalisasi yang berlebihan. Huntington tidak mau melihat kenyataan bahwa peradaban barat ataupun Islam sebenarnya tidak dapat diidentifikasikan sebagai satu identitas yang akan bertindak sama. Peradaban barat maupun Islam masing-masing memiliki variasi yang berbeda-beda. Didalam internal peradaban barat maupun Islam, mereka memiliki variasi dinamika tersendiri. Bahkan tidak jarang telah terjadi konflik di dalam satu peradaban yang sama (Yang, 2009), (Crone, 2014; Yang, 2009).

Selain kelemahan-kelemahan dari pendekatan teoritis, argumen Huntington dalam teori "Clash of Civilization" juga memiliki kelemahan dari sisi "historical aproach". Huntington telah berpendapat dalam bukunya bahwa konflik di era paska perang dingin banyak disebabkan karena adanya benturan antar peradaban yang berbeda. Namun sejarah telah membuktikan bahwa teori Huntington tersebut tidaklah benar. Karena fakta telah membuktikan bahwa konflik yang terjadi baik sebelum perang dingin, selama perang dingin, ataupun setelah (pasca) perang dingin, tidak terdapat korelasi yang signifikan mengenai hubungan antara peradaban dan konflik yang terjadi. Bahkan konflik yang terjadi baik sebelum, selama dan pasca perang dingin justru banyak terjadi antar negara-negara yang memiliki peradaban yang sama, misalnya konflik Bosnia, Teluk Persia dan NagornoKarabakh, konflik Sulu (Filipina)-Malaysia, bahkan konflik Indonesia-Timor Leste dan konflik antara pemerintah Indonesia-GAM. Dimana konflik-konflik yang terjadi tersebut bukan disebabkan oleh perbedaan peradaban, tetapi disebabkan oleh kepentingan (Henderson \& Tucker, 2001).

Pada masa pasca perang dingin banyak negara non-barat, (termasuk negara-negara Islam) yang kemudian bergabung kedalam sistem demokrasi. Dengan demikian justru fenomena yang terjadi adalah kebalikan dari tesis Huntington. Karena negara yang bergabung dalam sistem demokrasi atau "Joint Democracy" justru memiliki kemungkinan yang sangat kecil untuk berkonflik. Hal ini juga membuktikan bahwa Islam tidak menutup diri untuk melakukan akulturasi dengan peradaban ataupun kebudayaan di luar Islam. Bahkan pada realitasnya banyak negara-negara non-barat (termasuk negara-neagra Islam) yang bersedia mengadopsi modernisasi dari barat terutama dibidang tehnologi, kesehatan, kemampuan persenjataan dan yang lainnya, tanpa menjadi barat itu sendiri. Artinya beberapa kebudayaan dan peradaban barat dapat diakulturasikan oleh peradaban-peradaban non-barat, termasuk peradaban Islam. hal ini semakin menunjukkan kelemahan dari teori yang diajukan oleh Huntington.

Penempatan peradaban Islam sebagai peradaban yang dianggap sebagai "trouble maker" sebenarnya disebabkan oleh referensi tentang Islam yang digunakan oleh Huntington 
dalam membahas dimensi Islam dalam buku "The Clash of Civilization and the Remaking of World Order" tersebut. Dia tidak melihat kehidupan peradaban Islam yang mempu menunjukkan toleransi terhadap peradaban di luar Islam. misalnya Huntington tidak menggunakan referensi kehidupan Islam di Indonesia yang notabene merupakan negara dengan jumlah penduduknya yang memeluk agama Islam terbesar di dunia. Padahal, agama (termasuk Islam) dengan segala dimensinya, bisa menjadi faktor penting yang berpotensi mampu mempengaruhi pola hubungan internasional. Oleh karena itu, memahami agama (termasuk memahami Islam) sangat penting tanpa mencampuradukkannya dengan berbagai fenomena sosial yang diciptakan oleh agama itu sendiri (Sheikh, 2014).

\section{Islam di Indonesia Sebagai Model Peradaban Islam yang Inklusif}

Gambaran dimensi Islam yang ada dalam buku "The Clash of Civilization and the Remaking of World Order", berasal dari pemahaman Huntington mengenai Islam yang bersumber dari referensi Islam Timur Tengah yang untuk saat ini cenderung menunjukkan fenomena konflik. Sebut saja seperti Libya, Suriah, Iraq, Mesir, Yaman yang sering dilanda konflik. Fenomena itu yang dimaknai oleh Huntington bahwa Islam adalah peradaban yang seolah-olah selalu bersinggungan dengan kekerasan dan konflik.

Padahal seharusnya terlebih dahulu dia harus melakukan studi yang mendalam untuk memahami tentang "Islam" supaya dapat menggambarkan Islam secara komperehensif. Dimana menurut Hamim Ilyas dalam tulisannya, "ISLAM RISALAH RAHMAT DALAM ALQURAN (Tafsir Q.S. al-Anbiya', 21: 107)”, menyebutkan bahwa belum ada suatu kesepahan untuk memahami apa itu "Islam". Hamim Ilyas menyebutkan bahwa "Islam merupakan risalah rahmat yang telah populer di kalangan umat. Namun konsepnya -sepanjang pengetahuan penulis- belum dielaborasi secara serius dan memadai, sehingga pengetahuan tersebut tidak berkembang menjadi wacana yang menghasilkan ketentuan atau kriteria tentang keislamaan yang jelas dan operasional". Namun demikian, dia kemudian mencoba untuk menjelaskan "Islam" dengan cara menggunakan salah satu ayat yang ada di dalam AlQur'an untuk membangun kerangka konseptual terkait "Islam" itu sendiri. Ayat yang digunakan tersebut adalah Q.S. al-Anbiya', 21: 1107, yang artinya: "Kami tidak mengutusmu (Muhammad) kecuali untuk menjadi rahmat bagi seluruh alam”. Dalam tulisannya tersebut, Hamim Ilyas menyebutkan bahwa Islam merupakan suatu organisme yang hidup. Sehingga ketika Islam dinyatakan sebagai rahmat bagi seluruh alam semesta, maka berarti agama Islam itu memberikan kasih dan memberikan kebaikan secara aktual terhadap seluruh alam. "Islam" yang tidak memberikan kasih dan kebaikan secara aktual, berarti menjadi agama yang laknat. Kemudian dia menyimpulkan bahwa "Islam itu adalah rahmat dan agama yang tidak menjadi rahmat itu bukan Islam" (Ilyas, 2007).

Dalam tulisannya tersebut, Hamim Ilyas dengan jelas mengatakan bahwa "Islam itu adalah rahmat dan agama yang tidak menjadi rahmat itu bukan Islam". Hal tersebut menunjukkan bahwa Islam merupakan agama yang memberikah Rahmat, (dalam bahasa Arab: rahmah) yaitu riqqah taqtadli al-ihsan ila al-marhum, perasaan halus (kasih) yang kemudian mendorong untuk memberikan kebaikan kepada yang dikasihi, dan hal itu bersifat universal. Karena Islam harus memberikan rahmat kepada seluruh alam, dan bukan hanya bagi manusia saja, apalagi bagi orang muslim saja. Sehingga ketika Huntington menggambarkan secara panjang lebar terkait "Islam" dalam buku "The Clash of Civilization and the Remaking of World Order" dengan penjelasan yang cenderung "negatif" maka yang terjadi Hunitngton tidaklah sedang menjelaskan Islam. Tetapi dia sedang menjelaskan tentang peristiwa-peristiwa penyimpangan terhadap Islam.

Kemudian pandangan Huntington tentang Islam dalam bukunya tersebut dapat dengan mudah dinegasikan dengan fenomena model Islam yang ada di Indonesia. Dimana pada kenyataannya Indonesia yang merupakan negara dengan jumlah penduduk yang memeluk agama Islam terbesar di dunia memiliki fenomena kehidupan sosial masyarakatnya yang 
justru menunjukkan hal yang berbanding terbalik dengan gambaran Islam yang dibahas oleh Huntington dalam bukunya tersebut. Islam mayoritas di Indonesia (mayoritas orang yang memeluk agama Islam di Indonesia). mampu merepresentasikan bahwa Islam merupakan agama yang bisa mengakomodasi kepentingan yang tidak hanya menjadi kepentingan bagi umat Islam, tetapi juga kepentingan umat diluar Islam atau diluar peradaban Islam. Mayoritas umat Islam di Indonesia mampu mentoleransi peradaban di luar Islam demi tercapainya perdamaian yang merupakan bagian yang diajarkan dalam agama Islam itu sendiri. Dan Islam mayoritas di Indoneisa sudah membuktikan hal itu dari masuknya Islam pertama kali hingga berkembang menjadi agama terbesar di Indonesia saat ini.

Islam mayoritas di Indonesia (mayoritas orang yang memeluk agama Islam di Indonesia). mampu merepresentasikan bahwa Islam merupakan agama yang bisa mengakomodasi kepentingan tidak hanya bagi umat Islam, tetapi juga umat diluar Islam atau diluar peradaban Islam. Mayoritas umat Islam di Indonesia mampu mentoleransi peradaban di luar Islam demi tercapainya perdamaian yang merupakan bagian yang diajarkan dalam agama Islam itu sendiri. Dan Islam mayoritas di Indoneisa sudah membuktikan hal itu dari masuknya Islam pertama kali hingga berkembang menjadi agama terbesar di Indonesia saat ini. Hal tersebut dapat terwujud berkat lahirnya organisasi masyarakat yang berbasis agama Islam di Indonesia yaitu NU (Nahdlatul Ulama) dan Muhammadiyah, yang merupakan organisasi masyarakat berbasis agama Islam yang terbesar tidak hanya di indonesia, namun terbesar di dunia, sehingga NU dan Muhammadiyah dianggap sebagai representasi umat Islam di Indonesia mengingat secara jumlah anggotanya menjadi mayoritas atas keseluruhan pemeluk agama Islam di Indonesia.

Kedua organisasi Islam terbesar di dunia ini, menunjukkan fenomena yang bertolak belakang dengan apa yang telah digambarkan oleh Huntington dalam bukunya "The Clash of Civilization and the Remaking of World Order". NU dan Muhammadiyah yang notabene adalah organisasi Islam terbesar di dunia justru menunjukkan sikap-sikap yang inklusif atau terbuka dengan identitas-identitas kebudayaan non-muslim. Di Indonesia, dua organisasi masyarakat Islam terbesar di dunia ini memiliki peran yang sangat krusial dalam menjaga persatuan dan kesatuan bangsa Indonesaia dengan mengusung toleransi antar agama dan budaya yang berbeda. Bahkan ketika banyak organisasi Islam lain di Indonesia yang ingin memaksakan syariat Islam atau hukum Islam sebagai dasar hukum negara Indonesia, NU dan Muhammadiyah mengambil sikap lain dengan tetap konsisten mendukung Pancasila yang dianggap sebuah sistem yang lebih bisa menghargai hak asasi manusia (HAM) yang dimiliki orang-orang non-muslim. NU dan Muhammadiyah juga menunjukkan sikap bertoleransi antar agama ataupun antar budaya dan peradaban (Yusdani, 2006). Dua organisasi Islam besar ini tetap konsisten ingin menjaga nilai-nilai persatuan dan toleransi ditengah kondisi masyarakat yang memang memiliki keragaman budaya serta perbedaan keyakinan di Indonesia. Kedua ormas keagamaan terbesar di Indonesia itu sesungguhnya adalah representasi sejarah peradaban Islam di Indonesia yang sudah berlangsung begitu lama. Bermuara dari sumber yang sama (Rasulullah Saw), NU dan Muhammadiyah menjelma sebagai organisasi keagamaan yang mencerminkan tipologi masing-masing. Tentu saja, karakter dan watak yang dimiliki dari masing-masing organisasi ibarat jalan bercabang yang muaranya sama. Sehingga penulis sama sekali tidak bermaksud untuk mendikotomikan kedua belah pihak. Dengan kata lain NU dan Muhammadiyah memang memiliki perbedaan pada beberapa dimensi, namun kedua organisasi Islam terbesar di Indonesia ini mampu menunjukkan sikap toleransi yang tinggi sehingga kedua organisasi ini dapat di sandingkan dalam bingkai semangat menghargai perbedaan dan keterbukaan, terlebih pada dimensi peradaban secara luas dan kebudayaan pada level yang lebih khusus.

Andaikata muncul pertanyaan mana Islam yang benar-benar asli maka jawabannya jelas tak ada. Sebab semua umat Muslim di dunia niscaya sepakat bahwa Islam yang kaffah 
hanyalah merujuk kepada sosok Rasulullah Saw semata; tidak ada yang lain. Dan Islam sejak zaman Rasulullah hingga sekarang telah melintasi pergulatan waktu sangat panjang. Dinamika realitas yang terus jumbuh selama 15 abad itu terbendung menjubahi kehidupan umatnya (Mustofa, 2015). Sehingga NU dengan semangat keberagaman dan Muhammadiyah dengan semangat pembaharuan mampu menampilkan wajah Islam yang bisa dijadikan sebagai model dan acuan bagi umat Islam di seluruh dunia untuk bisa menghadirkan wajah Islam yang mengajarkan kedamaian sehingga mampu berkontribusi dalam menjaga perdamaian di seluruh dunia.

\section{Islam Nusantara (NU) dan Islam Berkemajuan (Muhammadiyah) Sebagai Praktik Islam "Inklusif" di Indonesia}

Model Islam di Indonesia yang bersifat inklusif, diartikulasikan ke dalam dua konsep yang dipraktikkan di Indonesia. Konsep yang pertama dinamakan "Islam Nusantara" yang diusung oleh Nahdlatul Ulama. Diskursus mengenai Islam Nusantara, menjadi dinamika tersendiri bagi perkembangan studi keislaman di Indonesia, terutama setelah terselenggaranya Muktamar Nahdlatul Ulama (NU) ke 33 pada bulan Agustus tahun 2015, dimana saat itulah diskursus tentang Islam Nusantara mulai dihembuskan. Definisi atau penjelasan mengenai Islam Nusantara memang masih dalam perdebatan, dan para intelektual Islam di Indonesia masih belum menemukan kata sepakat dalam memaknai konsep Islam Nusantara tersebut baik secara etimologi ataupun terminologi.

Namun demikian dalam tulisan ini akan dibahas terkait beberapa penjelasan atau definisi sebagai acuhan untuk memahami Islam Nusantara. Namun sebelumnya perlu diingat bahwa Islam Nusantara bukanlah sebagai ajaran, tetapi Islam Nusantara adalah bentuk perwujudan dari Islam secara faktual yang bisa dilihat secara sosiologis ataupun antropologis dalam masyarakat di "Nusantara (Indonesia)". Keberadaannya secara etimologi tentunya berbeda dengan Islam yang ada di Arab maupun yang ada di Barat (Irham, 2015).

Guru besar Filologi Oman Faturrahman, menjelaskan bahwa Islam Nusantara adalah Islam yang empirik dan distingtif sebagai hasil interaksi, kontekstualisasi, indigenisasi, penerjemahan dan vernakularisasi Islam universal dengan realitas sosial, budaya, dan sastra yang ada di Indonesia (Mahbib, 2015). Lebih lanjut, Faturrahman juga ikut merintis analisa untuk menjelaskan Islam Nusantara secara historis-filologis. Metode tersebut dilandaskan pada penyelidikan teks-teks islam lama atau kuno dari para ulama yang pernah hadir di Nusantara di masa lampau.

Sementara Mustofa Bisri, dalam melihat Islam Nusantara lebih menekankan sebagai "sistem nilai", dan juga penerapannya dalam menanggapi masalah-masalah aktual yang ada dari waktu ke waktu. Mustofa Bisri memaknai Islam Nusantara cenderung melihatnya pada nilai-nilai yang selama ini diterapkan, diresapi, dan dijadikan prinsip oleh warga NU, seperti tasamuh (toleran), tawazun (seimbang/harmoni), tawassut (moderat), ta'addul (keadilan), dan 'amr ma'ruf nahi munkar. Sehingga dalam konteks ini Islam Nusantara ditempatkan secara aksiologis (Luthfi, 2016a).

Selain itu, Islam Nusantara juga didekati secara historis antropologis. Dimana ketua PBNU Said Aqil Siradj, menyatakan : Islam Nusantara adalah Islam yang khas, yang ada di Indonesia, yang merupakan gabungan nilai Islam teologis dengan nilai-nilai tradisi lokal, budaya, serta adat istiadat yang ada di Indonesia. Dalam konteks ini, Said Aqil Siradj melihat bahwa budaya suatu daerah atau negara tertentu sejatinya memiliki posisi yang setara dengan budaya yang ada di negara Arab dalam menyerap dan menjalankan ajaran Islam. Tradisi Islam Nusantara menunjukkan tradisi Islam dari berbagai daerah yang ada di Indonesia, dan melambangkan kebudayaan Islam di Indonesia (Luthfi, 2016b).

Pengertian diatas secara unik hendak mendorong komparasi yang kritis terhadap Islam yang berkembang dalam kebudayaan Arab. Islam di Indonesia, atau di kawasan lain di dunia, pada prinsipnya bersifat sejajar dengan Islam versi Arab. Penafsiran atas Islam tidak 
dapat dimonopoli atau diseragamkan. Perbedaan-perbedaan sejarah, tradisi, hingga karya seni maupun sastra ikut membentuk perkembangan Islam disuatu negara atau masyarakat. Islam Nusantara mengutamakan relasi dan kesinambungannya dengan budaya local. Islam Nusantara berpijak pada perubahan yang sifatnya moderat, kompromis, dan menjauhi caracara kekerasan terhadap dinamika budaya masyarakat di Indonesia. Lebih lanjut Islam Nusantara pun dapat bertransformasi sebagai kekuatan kebangsaan dan kemajuan yang digelorakan oleh Soekarno pada masa-masa awal kemerdekaan Indonesia. Sehingga pada akhirnya kita dapat menarik kesimpulan bahwa secara sederhana Islam Nusantara dapat dipahami sebagai sebuah gagasan nilai yang terkandung dalam pemikiran mayoritas masyarakat nusantara (Indonesia) yang beragama Islam, dengan ciri-ciri utamanya yaitu sifat inklusifisme dan toleransi terhadap nilai-nilai di luar Islam yang berkembang di nusantara.

Kehadiran Islam Nusantara di Indonesia tidak dapat dilepaskan dari "orang tua kandungnya", yaitu organisasi masyarakat yang berbasis agama Islam di Indonesia yaitu NU (Nahdlatul Ulama), yang merupakan organisasi masyarakat berbasis agama Islam yang terbesar tidak hanya di indonesia, namun juga terbesar di dunia. Dimana NU pada tahun 2014 diperkirakan memiliki anggota kurang lebih 83 juta jiwa yang tersebar di seluruh Indonesia (Manshur, 2014). Sehingga anggota dari NU dianggap sebagai representasi umat Islam di Indonesia mengingat secara jumlah anggotanya menjadi mayoritas atas keseluruhan pemeluk agama Islam di Indonesia.

Nahdlatul 'Ulama (Kebangkitan 'Ulama atau Kebangkitan Cendekiawan Islam), disingkat NU, adalah sebuah organisasi Islam besar di Indonesia. Organisasi ini berdiri pada 31 Januari 1926 dan bergerak di bidang pendidikan, sosial, dan ekonomi. NU sebagai organisasi Islam yang besar sangat menjunjung tinggi nilai keberagaman. Hal ini dapat dilihat dari sejarah NU sendiri yang dilatarbelakangi oleh perjuangan kaum pesantren untuk memperjuangkan keberagaman dalam Islam.

Sikap mengahargai keberagaman dari NU, dapat dilihat dari perjuangan kaum pesantren (cikal bakal NU), Ketika Raja Ibnu Saud hendak menerapkan asas tunggal yakni mazhab wahabi di Mekah, serta hendak menghancurkan semua peninggalan sejarah Islam maupun pra-Islam, yang selama ini banyak diziarahi karena dianggap bid'ah. Kemudian kalangan pesantren yang selama ini membela keberagaman, menolak pembatasan bermadzhab dan penghancuran warisan peradaban tersebut. Sikapnya yang berbeda, kalangan pesantren dikeluarkan dari anggota Kongres Al Islam di Yogyakarta 1925, akibatnya kalangan pesantren juga tidak dilibatkan sebagai delegasi dalam Mu'tamar 'Alam Islami (Kongres Islam Internasional) di Mekah yang akan mengesahkan keputusan tersebut. Didorong oleh minatnya yang gigih untuk menciptakan kebebsan bermadzhab serta peduli terhadap pelestarian warisan peradaban, maka kalangan pesantren terpaksa membuat delegasi sendiri yang dinamai dengan Komite Hejaz, yang diketuai oleh KH. Wahab Hasbullah. Atas desakan kalangan pesantren yang terhimpun dalam Komite Hejaz, dan tantangan dari segala penjuru umat Islam di dunia, Raja Ibnu Saud mengurungkan niatnya. Hasilnya hingga saat ini di Mekah bebas dilaksanakan ibadah sesuai dengan madzhab mereka masing-masing. Itulah peran internasional kalangan pesantren pertama, yang berhasil memperjuangkan kebebasan bermadzhab dan berhasil menyelamatkan peninggalan sejarah serta peradaban yang sangat berharga. Berangkat dari komite dan berbagai organisasi yang bersifat embrional dan ad hoc, maka setelah itu dirasa perlu untuk membentuk organisasi yang lebih mencakup dan lebih sistematis, untuk mengantisipasi perkembangan zaman. Maka setelah berkordinasi dengan berbagai kiai, akhirnya muncul kesepakatan untuk membentuk organisasi yang bernama Nahdlatul Ulama (Kebangkitan Ulama) pada 16 Rajab 1344 H (31 Januari 1926). Organisasi ini dipimpin oleh KH. Hasyim Asy'ari sebagi Rais Akbar.

Dilihat dari sejarah kemunculan Nahdlaul Ulama sudah menggambarkan betapa semangat untuk menghargai keberagaman yang ada di dalam organisasi tersebut menjadi 
fondasi awal terbentuknya organisasi Islam terbesar ini. Bahkan semangat keberagaman tersebut pada awalnya justru muncul sebagai gerakan menghargai perbedaan yang memberikan kontribusi di level internasional, yang kemudian dampak dari perjuangan tersebut bisa dirasakan oleh masyarakat secara luas hingga saat ini. NU didirikan untuk menciptakan kehidupan yang beradab dan memberikan manfaat bagi seluruh alam semesta. Tidak hanya bagi orang Islam saja, apalagi untuk anggota NU saja. Hal tersebut tercermin dari muqadimmah dalam anggaran dasar Nahdlatul Ulama 2010 yang berbunyi:

\section{"Bahwa agama Islam merupakan rahmatan lil 'alamin (rahmat bagi semesta alam) dengan ajaran yang mendorong terwujudnya kemaslahatan dan kesejahteraan hidup bagi segenap umat manusia di dunia dan akhirat (Preambule of Article of Association of Nahdlatul Ulama, 2010).}

Dari kutipan muqadimmah dalam AD/ART Nahdlatul Ulama tersebut menunjukkan bahwa NU didirikan bukan hanya untuk memberikan manfaat bagi masyarakat Islam saja, apalagi hanya untuk anggota dari Nahdlatul Ulama itu sendiri. Tapi NU didirikan dengan tujuan memberikan manfaat bagi semua alam dan seisinya, termasuk didalamnya masyarakatmasyarakat diluar peradaban Islam baik yang ada di Indonesia ataupun pada level internasional. Semangat pergerakan NU dalam dimensi dakwah atau memperkenalkan dan mempromosikan Islam kepada dunia sangat dipengaruhi oleh sejarah penyebaran agama Islam yang dilakukan secara damai oleh walisongo.

Transmisi Islam yang dipelopori Walisongo merupakan perjuangan brilian yang diimplementasikan dengan cara sederhana, yaitu menunjukkan jalan dan alternatif baru yang tidak mengusik tradisi dan kebiasaan lokal, serta mudah ditangkap oleh orang awam dikarenakan pendekatan-pendekatannya konkrit dan realistis, tidak njelimet, dan menyatu dengan kehidupan masyarakat. Model ini menunjukkan keunikan sufi Jawa yang mampu menyerap elemen-elemen budaya lokal dan asing, tetapi dalam waktu yang sama masih berdiri tegar di atas prinsip-prinsip Islam (Minftahuddin, 2015). Semangat perjuangan Walisongo inilah yang menjadi semangat perjuangan ormas NU hingga saat ini. Sehingga nampak jelas bahwa Islam yang diusung oleh NU merupakan penempatan agama dan keyakinan yang bisa memberikan kesejahteraan dan manfaat bagi semua kalangan masyarakat sekalipun masyarakat yang posisinya diluar Islam.

Selain kehadiran NU dengan konsep Islam Nusantara, Indonesia juga memiliki Muhammadiyah yang mengembangkan dan mempraktikkan konsep Islam Berkemajuan. Muhammadiyah adalah salah satu organisasi Islam yang besar di Indonesia. Nama organisasi ini diambil dari nama Nabi Muhammad SAW, sehingga Muhammadiyah juga dapat dikenal sebagai orang-orang yang menjadi pengikut Nabi Muhammad SAW. Organisasi Muhammadiyah didirikan oleh K.H. Ahmad Dahlan di Kampung Kauman Yogyakarta pada tanggal 18 November 1912 (8 Dzulhijjah $1330 \mathrm{H}$ ).

Muhammadiyah merupakan sebuah organisasi Islam besar, yang memiliki cita-cita ingin memurnikan ajaran Islam yang selama ini dianggap dalam pengamalannya masih belum murni dan banyak dipengaruhi oleh ajaran-ajaran dari kepercayaan yang lain. Tetapi meskipun demikian dalam level hubungan antar umat beragama ataupun hubungan dengan masyarakat diluar peradaban Islam, Muhammadiyah memiliki sifat-sifat yang bisa menghargai peradaban ataupun kebudayaan diluar peradaban atau kebudayaan Islam. Perjuangan Muhammadiyah memang berfokus pada pemurnian ajaran Islam, tetapi dengan tidak memarjinalkan peradaban-peradaban ataupun kebudayaan diluar Islam. Bahkan Muhammadiyah dianggap sebagai organisasi Islam yang paling berkompromi dengan modernisasi.

Sikap kepedulian Muhammadiyah terhadap masyarakat yang memiliki kebudayaan ataupun perdadaban, bahkan kepercayaan atau agama yang berbeda dapat kita lihat dalam 
Matan Keyakinan dan Cita-cita Hidup Muhammadiyah. Jika kita merujuk dari Matan Keyakinan dan Cita-cita Hidup Muhammadiyah, dapat kita lihat bahwa Muhammadiyah dalam konteks hubungan sosial dengan masyarakat yang memiliki keyakinan, budaya, serta peradaban yang berbeda maka Muhammadiyah lebih mengedepankan pada terciptanya kehidupan yang adil dan sejahtera yang tidak hanya ditujukan kepada umat Islam atau anggota Muhammadiyah saja tetapi semua masyarakat. Hal tersebut dengan jelas tertuang pada poin pertama Matan Keyakinan dan Cita-cita Hidup Muhammadiyah. Dimana "Muhammadiyah bercita-cita dan bekerja untuk terwujudnya masyarakat utama, adil, makmur yang diridhai Allah SWT, untuk malaksanakan fungsi dan misi manusia sebagai hamba dan khalifah Allah di muka bumi". Dalam poin ini Muhammadiyah memiliki harapan untuk terciptanya masyarakat utama, adil, makmur. Masyarakat yang dimaksud bukan hanya masyarakat muslim atau masyarakat Muhammadiyah, tetapi masyarakat secara umum.

Terkait dengan praktik gerakan Muhammadiyah telah mengusung gagasan Islam Berkemajuan. Gagasan ini sendiri mulai hangat diperbincangkan, bahkan di kalangan internal Muhammadiyah sendiri, sejak konsep ini mulai dimunculkan dalam Muktamar Muhammadiyah yang ke-46 pada tahun 2010 yang diselenggarakan di Yogyakarta. Namun munculnya konsep tersebut pada tahun 2010 masih menjadi sebatas wacana publik, hingga kemudian wacana Islam Berkemajuan tersebut ditegaskan sebagi jati diri gerakan Muhammadiyah yang dikenal dengan istilah "gerakan pencerahan" pada Muktamar berikutnya yang diselenggarakan di Makasar pada tahun 2015 (Maarif, 2020).

Istilah Islam Berkemajuan sendiri dapat dimaknai sebagai bentuk respon warga Muhamadiyah terhadap globalisasi. Dengan adanya globalisasi yang seolah tidak terbendung, lantas Muhammadiyah mengambil sikap untuk menonjolkan sifat Islam yang kosmopolitan. Artinya Muhamadiyah secara sadar menganggap dirinya sebagai agian dari masyarakat global yang sudah seharusnya juga memberkan kontribusi terhadap kemajuan global, yang tidak hanya terbatas pada warga Muslim saja, atau warga Indonesia saja, apalagi hanya terbatas pada warga Muhammadiyah saja (Burhani, 2016). Gerakan untuk memajukan yang dilakukan Muhammdiyah berlaku global tanpa batas wilayah dan identitas sebagaimana sifat Islam yang diturunan untuk dapat bermanfaat bagi seluruh alam semesta. Sehingga kelahiran gerakan Islam Berkemajuan dengan mengambil posisi sebagai Islam Kosmopolitan dalam globalisasi menunjukkan bahwa Muhammadiyah juga siap untuk berkolaborasi dengan peradaban di luar Islam untuk bersama-sama membangun peradaban yang inklusif.

Konsep Islam Berkemajuan yang diusung oleh Muhammadiyah di tengah globalisasi yang disebabkan oleh perkembangan teknologi informasi dan komunikasi adalah sebagai bentuk penyesuaian diri yang dilakukan oleh Muhammadiyah dengan cara mempertegas jati diri yang selama ini memang sudah melekat pada diri Muhammadiyah itu sendiri sejak kelahiran orgaisasi tersebut, yang memang terlahir dengan semangat memberikan manfaat bagi alam semesta. Perubahan yang sangat cepat serta arus interaksi global yang sangat masiv dengan adanya revolusi insudtri dan transportasi membuat Muhammadiyah semakin yakin untuk menempati posisi sebagai salah satu organisasi Islam terbesar di dunia untuk memberikan kontribusi terhadap perkembangan dunia global dengan konsep "Islam Berkemajuan". Kata berkemajuan sendiri sejatinya sudah sangat melekat pada gerakan Muhammadiyah. Misalanya saja kita bisa melacak sejarah kata berkemajuan sendiri yang dalam beberapa kesempatan diutarakan oleh sang pendiri Muhammadiyah itu sendiri yaitu Kiai Dahlan, yang pernah menyampaikan istilah "pemimpin kemajuan Islam" dalam tulisannya yang berjudul "Tali Pengikat Hidup Manusia". Selain itu Kiai Dahlan juga pernah menyampaikan bahwa menjadi ulama atau kiya harus berkemajuan dan pantang lelah untuk berkonribusi terhadap Muhammadiyah (Kahfi, 2018). Dengan demikian keberadaan gagasan Islam Berkemajuan, sebenarnya bukanlah hal baru bagi Muhammadiyah. 
Peran Muhammadiyah yang bersifat kosmopolitan demi kemajuan umat manusia di dunia dibuktikan dengan berbagai kiprah Muhammadiyah dalam berbagai bidang di dunia internasional. Misalnya saja Muhamadiyah secara aktif dalam kegiatan-kegiatan kemanusiaan yang bersifat lintas batas negara. Melalui Muhammadiyah Disaster Management Center (MDMC) misalnya, Muhammadiyah sering terlibat dalam mengatasi krisi kemanusiaan yang terjadi di dunia internasional. tidak hanya itu, di bidang pendidikan, Muhammadiyah juga mengembangkan sayap Islam berkemajuan untuk berkontribusi terhadap pembangunan peradaban dunia. Selain berperan aktif dalam dunia pendidikan di Indoensia, Muhammadiyah pada tahun 2021 juga sudah mulai berkontribusi di bidang pendidikan di negara lain, dengan mendirikan universitas Muhammadiyah di Malaysia dengan nama dengan nama Universiti Muhammadiyah Malaysia(UMAM). Selain itu pada tahun yang sama, Muhammadiyah juga resmi Muhammadiyah medapatkan izin pembukaan sekolah pada jenjang kanak-kanak hingga Sekolah Dasar dari Pemerintah Australia melalui Victorian Registration and Qualifications Authority (VRQA) Department Education Victoria. Sekolah tersebut diberi nama Muhammadiyah Australia College (MAC). Dengan demikian, Islam Berkemajuan tidak lagi hanya sebagai wacana bagi Muhammadiyah untuk menunjukkan kontribusinya terhadap dunia internasional, tetapi secara pasti Muhammadiyah sudah melakukannya secara praktik.

\section{SIMPULAN}

Dari pembahasan dalam tulisan ini, dapat ditarik beberapa kesimpulan, yang akan menuntun kita untuk memahami dimensi Islam yang dibahas oleh Huntington, dalam bukunya yang berjudul "The Clash of Civilization and the Remaking of World Order". Dalam penjelasannya mengenai Islam, Huntington terlalu memojokkan Islam dengan melakukan generalisasi yang berlebihan. Huntington gagal memahami Islam itu sendiri secara objektif. Dalam memberikan gambaran mengenai Islam yang diprediksikan akan berbenturan dengan barat hanya dengan memaknai beberapa contoh kasus yang kebetulan dilakukan oleh beberapa orang yang juga secara kebetulan juga memeluk agama Islam. Selain itu konseptual yang dibangun huntington tentang peradaban "barat" dan peradaban "Islam" juga tampak jelas kerancuan indikator yang digunakan. Apakah menggunakan klasifikasi wilayah, agama, kebudayaan, tidak terlalu jelas dan membingungkan.

Namun yang jauh lebih penting daripada itu dapat disimpulkan dalam tulisan ini bahwa model Islam di Indonesia yang dipraktikkan oleh dua organisasi Islam terbesr di dunia yaitu Nahdlatul Ulama (NU) dengan konsep "Islam Nusantara" dan Muhammadiyah dengan konsep "Islam Berkemajuan" yang ada di Indonesia, mampu menunjukkan sifat yang bertolak belakang dengan Islam yang digambarkan oleh Huntington dalam bukunya tersebut. Model Islam Nusantara dan Islam Berkemajuan yang bisa kita lihat perwujudannya dalam organisasi Islam terbesar di dunia yaitu NU dan Muhammadiyah mampu menunjukkan sikap toleransi dan menjalankan Islam sebagai agama yang mampu memberikan manfaat bagi semua. Dengan kata lain model Islam inklusif di Indonesia telah membuktikan bahwa teori yang dibangun oleh Huntington tentang benturan antar peradaban serta pembahasan dimensi Islam dalam bukunya yang berjudul "The Clash of Civilization and the Remaking of World Order", kurang tepat.

\section{DAFTAR PUSTAKA}

Ashraf, M. M. T. (2012). The Clash of Civilizations? A Critique. Pakistan Journal of Social Sciences (PJSS), 32(2), 521-527. Retrieve From https://www.bzu.edu.pk/PJSS/Vol32No22012/Final_PJSS-32-2-19.pdf

Burhani, A. N. (2016). Islam Nusantara VS Berkemajuan. In A. Mu'ti, F. R. Ulhaq, A. Khoirudin, \& A. F. Fanani (Eds.), Kosmopolitanisme Islam Berkemajuan Catatan Kritis 
Muktamar Teladan ke-47 Muhamamdiyah di Makasar 2015 (1st ed.). Surakarta: Muhammadiyah University Press.

Crone, M. (2014). Religion and Violence: Governing Muslim Militancy through Aesthetic Assemblages. Millennium, 43(1), 291-307. https://doi.org/10.1177/0305829814541166

Fukuyama, F. translated by M. A. (2004). The End of History and The Last Man. Yogyakarta: Qalam.

Henderson, E. a, \& Tucker, R. (2001). Clear and Present Strangers: The Clash of Civilizations and International Conflict. International Studies Quarterly, 45(February 1999), 317-338. https://doi.org/10.1111/0020-8833.00193

Huntington, S. P. translated by Ismail, M. S. (2012). THE CLASH OF CIVILIZATION AND THE REMAKING OF WORLD ORDER. Yogyakarta: Qalam.

Huntington, S. P. (1993). The clash of civilization? Foreign Affairs. https://doi.org/10.2307/1252166

Ilyas, H. (2007). Islam Risalah Rahmat Dalam Al-Quran ( Tafsir Q . S . al-Anbiya ', 21 : 107). Hermeneia: Jurnal Kajian Islam Interdisipliner, 6(2), 257. Retrieved from http://digilib.uin-

suka.ac.id/id/eprint/8500/1/HAMIM\%20ILYAS\%20\%20ISLAM\%20RISALAH\%20RA HMAT\%20DALAM\%20AL-QURAN\%20(TAFSIR\%20Q.S.\%20AL-

ANBIYA',\%202I\%20IOY).pdf

Irham. (2015). Mengaji Islam Nusantara Sebagai Islam Faktual _ NU Online. Retrieved January 29, 2017, from http://www.nu.or.id/post/read/61182/mengaji-islam-nusantarasebagai-islam-faktual

Kahfi, M. (2019). Muhammadiyah Gerakan Islam Berkemajuan: Selayang Pandang. SIASAT, 3(1), 39-46. https://doi.org/10.33258/siasat.v2i1.15

Luthfi, K. M. (2016a). Islam Nusantara: Relasi Islam dan Budaya Lokal. SHAHIH : Journal of Islamicate Multidisciplinary, 1(1), 1. https://doi.org/10.22515/shahih.v1i1.53

Luthfi, K. M. (2016b). Kontekstualisasi Filologi dalam Teks-teks Islam Nusantara. IBDA ' : Jurnal Kajian Islam Dan Budaya, 14(1), 114-128. https://doi.org/10.24090/ibda.v14i1.523

Maarif, A. S. (2020). Islam Berkemajuan, Apa Itu? (I). Suara Muhamadiyah. Retrieved from https://suaramuhammadiyah.id/2020/05/08/islam-berkemajuan-apa-itu-i/

Mahbib. (2015). Apa yang Dimaksud dengan Islam Nusantara? NU Online. Retrieved from http://www.nu.or.id/post/read/59035/apa-yang-dimaksud-dengan-islam-nusantara

Manshur, I. (2014). Jumlah Warga NU 83 Juta Jiwa di Indonesia, Benarkah? Retrieved January 1, 2017, from http://www.muslimedianews.com/2014/05/jumlah-warga-nu-83juta-jiwa-di.html

Minftahuddin, M. (2015). Islam Moderat Konteks Indonesia Dalam Perspektif Historis. MOZAIK: Jurnal Ilmu-Ilmu Sosial Dan Humaniora, 5(1). 
Mufid, A. S. (2013). Paham Ahlu Sunnah Wal Jama'ah Dan Tantangan Kontemporer Dalam Pemikiran Dan Gerakan Islam Di Indonesia. Harmoni, 12(3), 8-18. Retrieved from https://jurnalharmoni.kemenag.go.id/index.php/harmoni/article/view/149

Mustofa, S. (2015). Meneguhkan Islam Nusantara Untuk Islam Berkemajuan: Melacak Akar Epistemologis dan Historis Islam (di) Nusantara. Epistemé: Jurnal Pengembangan Ilmu Keislaman, 10(2). https://doi.org/10.21274/epis.2015.10.2.405-434

Preambule of Article of Association of Nahdlatul Ulama (2010). Indonesia.

Sheikh, M. K. (2014). The Religious Challenge to Securitisation Theory. Millennium: Journal of International Studies, 43(1), 252-272. https://doi.org/10.1177/0305829814540853

Yang, Y. (2009). Analyze the One-Sidedness of "Clash of Civilizations." Journal of Politics and Law, 2(3). https://doi.org/10.5539/jpl.v2n3p97

Yusdani, Y. (2006). Formalisasi Syariat Islam dan Hak Asasi Manusia di Indonesia. AlMawarid, 16. https://doi.org/10.20885/almawarid.vol16.art7 